\title{
Water Uptake and Indoleacetic Acid Destruction of Cultured Bean Germ-Axes
}

\author{
by Mitsuo IzawA*
}

Received July 29, 1960

Generally water uptake of plant tissues is said to be in an intimate correlation with their auxin content ${ }^{1}$ ). Some authors are of opinion that the decrease in auxin destroying activity is a critical factor for cessation of water uptake or elongation of the tissues ${ }^{2}$ ).

In a previous paper ${ }^{3}$ ) it was reported that indoleacetic acid (IAA) remarkably affects the changes in fresh weight or water content of cultured germ-axes of a bean, Vigna sesquipedalis. Thus, the fresh weight of the germ-axes which increases gradually in the absence of IAA added, changes little in a IAA $(1 \mu \mathrm{g} . / \mathrm{m} l$. $)$ containing medium for the first 2 days of culture, and then it begins to rise strikingly. That is to say, the exogenously supplied IAA apparently causes temporary inhibition of water uptake.

The present report concerns with this anomalous effect of IAA on water uptake of cultured bean germ-axes. It will be indicated that surplus auxin may inhibit not only water uptake but also IAA destroying activity of the tissues. The presence of a dialyzable substance in the tissues which can exert promotion at lower concentrations and inhibition at higher concentrations on IAA destroying system will also be demonstrated.

\section{Materials and Methods}

Seeds of Vigna sesquipedalis stored for about a year after harvest were used. The methods of isolation and culture of germ-axes were described elsewhere ${ }^{3}$ ).

Preparation of crude extract: Fifty to 60 germ-axes were harvested daily and homogenized with $30 \mathrm{ml}$. of $0.03 \mathrm{M}$ phosphate buffer $(\mathrm{pH} \mathrm{6.0)}$ and sea sand in a porcelain mortar. The brei was centrifuged at $1,000 \times \mathrm{g}$ (Kubota centrifuge, Model $\mathrm{K}-80$ ) for 10 minutes to obtain crude extract of the tissues. Homogenization and centrifugation were conducted in a cold room at ca. $4^{\circ}$.

Dialysis: Thirty $\mathrm{m} l$. of crude extract was placed in a seamless cellulose tube (A. H. Thomas Co., Philadelphia) and dialyzed against ca. $3 l$. of distilled water for 24 hours with continuous stirring (a magnetic stirrer used) in the cold room to obtain dialyzed extract. The dialyzate solution, when its effect on IAA destroying activity was examined, was concentrated under reduced pressure at room temperature down to ca. $10 \mathrm{ml}$. (referred to as dialyzate).

Fractionation of crude extract: Crude extract (ca. $30 \mathrm{ml}$.) was centrifuged at $10,000 \times \mathrm{g}$ (Servall centrifuge, Model SS-1) for 20 minutes to separate mitochondrial fraction from supernatant fraction. The sedimented pellet (mitochondrial fraction) was suspended in $6 \mathrm{ml}$. of $0.03 \mathrm{M}$ phosphate buffer $(\mathrm{pH} 6.0$ ) before use.

Measurement of IAA destroying activity: The reaction medium contained routinely $0.6 \mathrm{mg}$. IAA (free acid, Merck), $0.03 \mathrm{M}$ phosphate buffer ( $\mathrm{pH} \mathrm{6.0)}$ and designated

* Biological Institute, Faculty of Science, Nagoya University, Chikusa, Nagoya, Japan. 
amount of crude or dialyzed extract, mitochondrial or supernatant fraction; total volume was $10 \mathrm{ml}$. When needed, $\mathrm{MnCl}_{2}\left(10^{-4}-10^{-7} \mathrm{M}\right)^{*}$, hydrogen peroxide $\left(10^{-4} \mathrm{M}\right)^{* *}$, 2,4-dichlorophenol $\left(10^{-4}-10^{-7} \mathrm{M}\right)$, hydroquinone $\left(10^{-5}-10^{-7} \mathrm{M}\right)$ or diluted dialyzate (1:10-1:1,000 by volume) was further added to the reaction medium. A shaking apparatus in a dark room was used; reaction temperature $30^{\circ}$. IAA destroying activity of extract or fraction was assayed as the amount of IAA ( $\mu$ g.) disappeared from the medium in one hour per protein- $\mathrm{N}$ (mg.). IAA was estimated colorimetrically as described by Galston and Dalberg ${ }^{2}$. Protein was precipitated with $10 \%$ trichloroacetic acid, and its nitrogen was estimated by Levy-Palmer's method. ${ }^{4}$ )

\section{Results}

\section{IAA destruction in crude extract.}

IAA destroying ability of crude extracts prepared from germ-axes which were harvested daily is shown in Fig. 1. Two facts are noted in this figure: one is that in control culture (grown without exogenous IAA) the ability was the highest in 2 day-old culture and thereafter gradually declined until it was lost entirely on the 7th day. This result appears to be incompatible with Galston and Dalberg ${ }^{2}$ ) and Pilet

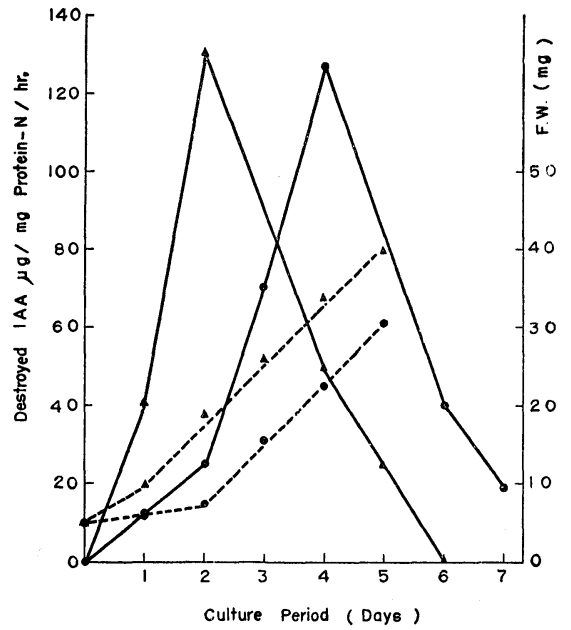

Fig. 1. IAA destruction in crude extracts and fresh weight of control and IAA cultures of various ages. Solid lines: IAA destruction, broken lines: fresh weight. Triangles: control culture, circles: $I A A$ culture. and Galston ${ }^{5}$ ) who indicated that IAA destroying activity of crude homogenates from pea epicotyl and Lens root increased with the age of the tissues. The other fact to be noted is that in IAA culture (grown with exogenous IAA) the ability was remarkably low for the initial 2 days. But after that time the activity showed a similar rise and fall to that observed in control culture. The pattern was not changed even if the culture medium (containing IAA) was renewed daily. As seen in the figure, this transitory depression of IAA destroying ability at the initial stage of IAA culture kept pace with the inhibition of water uptake of the tissues. The parallelism was undetectable in later period of culture when IAA destroying activity sharply declined independently of the water uptake. These facts also appear to be incompatible with the findings of other authors ${ }^{2,5}$ ) that in pea epicotyl and Lens root the drop in IAA destroying activity accompanies the rise in water uptake and vice versa.

\section{Effect of dialysis on crude extract.}

In order to examine the mechanism of the inhibition of IAA destroying activity in the later culture period of both control and IAA cultures as well as in the early period of $I A A$ culture, the effect of dialysis on crude extracts prepared from either

* Figures in parentheses indicate the final concentrations.

** Hydrogen peroxide of higher concentration $\left(>10^{-4} \mathrm{M}\right)$ was found to destroy IAA nonenzymatically. 
control or IAA culture of various ages was examined (Fig. 2). As shown clearly in the figure, the initial depression of the activity in $I A A$ culture was nearly unaffected by dialysis, whereas the inhibition in the later stage of control and IAA cultures. was removed entirely by dialysis. Moreover, the activity of dialyzed extract prepared from germ-axes in the later culture period was found to be hardly decreased by prolonged ( 2 to 3 day-long) dialysis. These facts suggest that the inhibition at the later stage of both cultures is due to some dialyzable substance(s), whereas the inhibition at the initial stage of IAA culture has nothing to do with such dialyzable inhibitor but likely is ascribed to the decrease in IAA destroying activity induced by exogenous IAA.

Effects of manganese, hydrogen peroxide, phenols and "dialyzate" on IAA destruction.

It is known that IAA destruction in plant tissues is an oxidative reaction catalyzed by peroxidase system, which is seriously affected by various substances such as $\mathrm{Mn}^{++}, \mathrm{H}_{2} \mathrm{O}_{2}$, monophenols and polyphenols $\left.{ }^{6,7,8}\right)$.

The effect of the addition of 2, 4-dichlorophenol (DCP) on crude and dialyzed extracts prepared from 2 day-old control culture is seen in Fig. 3(a). DCP was found to act inhibitorily on crude extracts

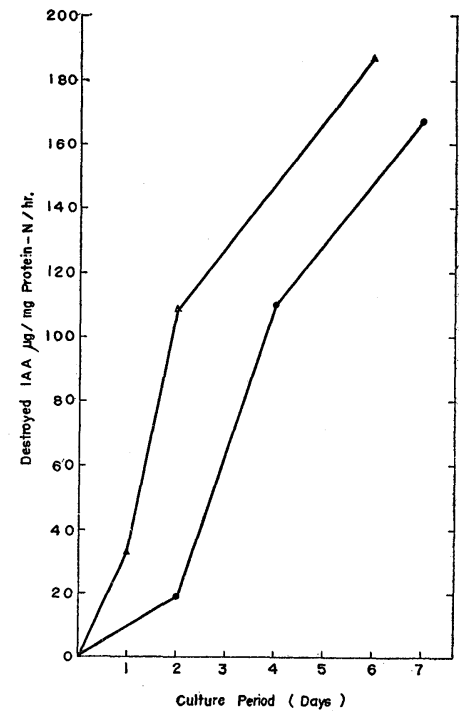

Fig. 2. IAA destruction in dialyzed extracts from control and IAA cultures of various ages. For symbols see the legend of Fig. 1. even at as low concentration as $10^{-7} \mathrm{M}$, while stimulatively on dialyzed extracts at $10^{-6}-10^{-7} \mathrm{M}$. At higher concentrations $\left(\geqq 10^{-5} \mathrm{M}\right)$, however, DCP acted inhibitorily even on dialyzed extracts. Fig. 4(a) indicates that IAA destruction by crude and dialyzed extracts prepared from 5 day-old control culture is affected by DCP in a similar way to the case of the extracts from 2 day-old control culture. On the other hand, DCP had no effect of increasing but only that of decreasing the weak IAA destroying activity of either crude or dialyzed extract from 2 day-old IAA culture (Fig. 5(a)). Although no detailed description is given, DCP did not affect at all crude and dialyzed extracts prepared from 0 day-old germ-axes. The results obtained by other authors with other materials do not always coincide with the present data. For example, higher amounts of DCP $\left(10^{-4}-10^{-6} \mathrm{M}\right)$ were reported to stimulate IAA destruction of crude homogenates prepared from pea epicotyls or wheat leaves $^{2,6}$. As generally accepted, DCP may act in IAA destroying system as a substitute for a naturally occurring phenolic cofactor ${ }^{9}, 10$ ), and these discrepancies may be explained in terms of the difference in concentration of endogenous phenolic cofactor. Thus bean crude extract may contain optimal amount of the cofactor, and exogenously supplied excess DCP would act only inhibitorily on IAA destroying system. On the other hand, in dialyzed extract the cofactor level may have been dropped sufficiently by dialysis, and now exogenous DCP can stimulate IAA destruction.

Hydroquinone $\left(10^{-5} \mathrm{M}\right)$ acted only inhibitorily on both crude and dialyzed extracts from control and IAA cultures of various ages (Figs. 3(b), 4(b) and 5(b)). This polyphenol, as a substrate for peroxidase, may compete with IAA for the enzyme action under consideration $\left.{ }^{6,8}\right)$. 


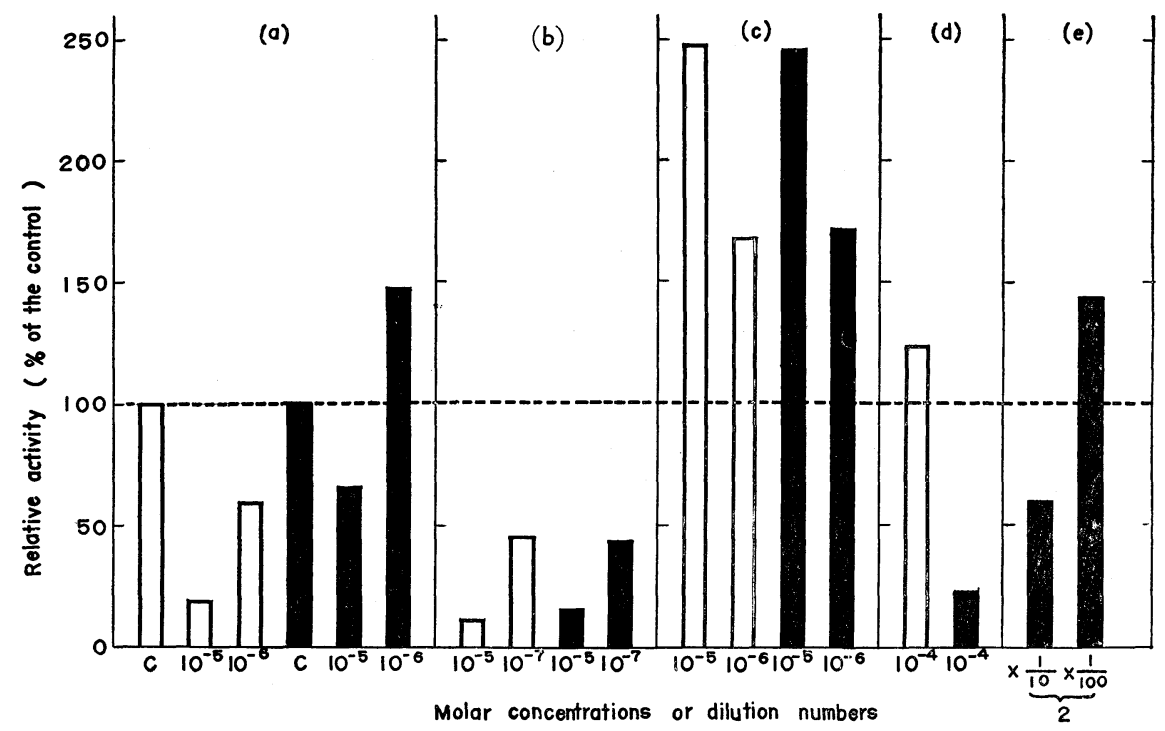

Fig. 3. Effects of 2, 4-dichlorophenol (DCP), hydroquinone, $\mathrm{Mn}^{++}, \mathrm{H}_{2} \mathrm{O}_{2}$ and dialyzate on IAA destruction in crude (blank bars) and dialyzed (filled bars) extracts prepared from 2 day-old control culture. Figures shown on the abscissa are molar concentrations or dilution numbers (in (e)) of the additions.

(a): control (C) and DCP effect,

(b): hydroquinone effect,

(c): $\mathrm{Mn}^{++}$effect,

(d): $\mathrm{H}_{2} \mathrm{O}_{2}$ effect,

(e): dialyzate (prepared from 2 day-old control culture) effect.

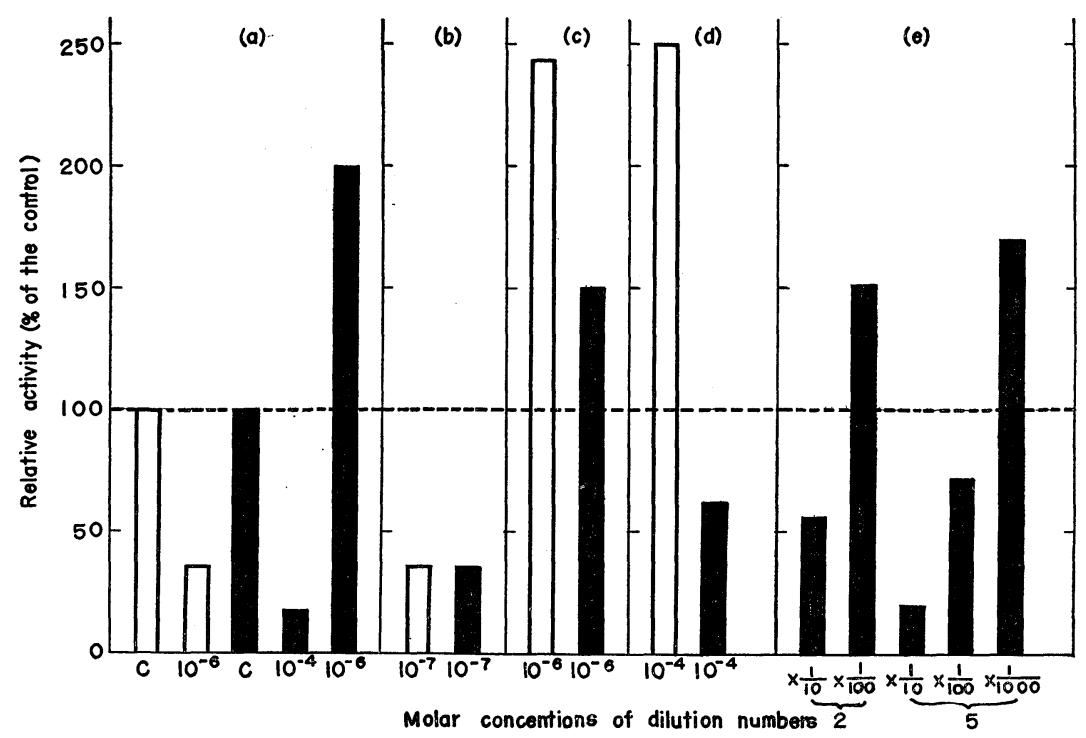

Fig. 4. Effects of DCP, hydroquinone, $\mathrm{Mn}++, \mathrm{H}_{2} \mathrm{O}_{2}$ and dialyzate on IAA destruction in crude and dialyzed extracts prepared from 5 day-old control culture. Dialyzates prepared from 2 and 5 day-old control cultures were examined respectively. For further details see the legend of Fig. 3. 


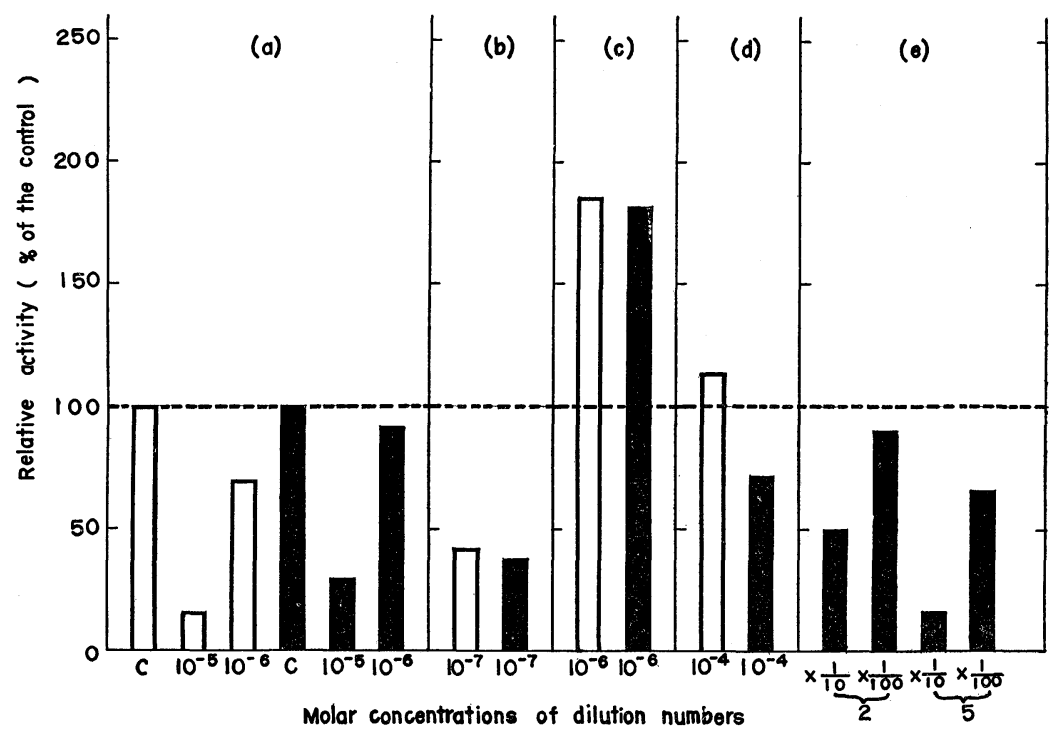

Fig. 5. Effects of DCP, hydroquinone, $\mathrm{Mn}^{++}, \mathrm{H}_{2} \mathrm{O}_{2}$ and dialyzate on IAA destruction in crude and dialyzed extracts prepared from 2 day-old IAA culture. Dialyzates prepared from 2 and 5 day-old control cultures were examined respectively. For further details see the legend of Fig. 3.

Hydrogen peroxide acted promotively on crude extract from every culture. This may again relate to the participation of peroxidase in IAA destroying action. The reagent, however, acted rather inhibitorily on dialyzed extract regardless of culture conditions of the source materials (Figs. 3(d), 4(d) and 5(d)). The mechanism of this inhibition is not yet clear. It was also found that hydrogen peroxide could not evoke any IAA destroying activity in the extracts from 0 day-old germ-axes.

Table 1. Recovering effect of $\mathrm{Mn}^{++}$on IAA destroying activity inhibited by $\mathrm{DCP}$, hydroquinone or dialyzate.

\begin{tabular}{l|r}
\hline \multicolumn{1}{c|}{ Additions to reaction medium* } & $\begin{array}{r}\text { IAA destroyed } \\
(\mu \mathrm{g} . / \mathrm{mg} \text {. protein-N/hr. })\end{array}$ \\
\hline none (control) & 112 \\
+ DCP $\left(10^{-5} \mathrm{M}\right)$ & 22 \\
+ DCP $\left(10^{-5} \mathrm{M}\right)+\mathrm{Mn}++\left(10^{-5} \mathrm{M}\right)$ & 208 \\
+ hydroquinone $\left(10^{-5} \mathrm{M}\right)$ & 15 \\
+ hydroquinone $\left(10^{-5} \mathrm{M}\right)+\mathrm{Mn}^{++}\left(10^{-5} \mathrm{M}\right)$ & 18 \\
+ dialyzate $(\times 1 / 10)^{* *}$ & 20 \\
+ dialyzate $(\times 1 / 10)+\mathrm{Mn}^{++}\left(10^{-5} \mathrm{M}\right)$ & 204 \\
\hline
\end{tabular}

* Reaction medium: $0.6 \mathrm{mg}$. IAA in $2 \mathrm{~m} l$. of $0.03 \mathrm{M}$ phosphate buffer (pH 6.0), $5 \mathrm{ml}$. of enzyme solution, crude extract prepared from 2 day-old control culture, made up to $10 \mathrm{ml}$. with the buffer.

** Dialyzate (see 'Dialysis' in Materials and Methods) diluted 10 times by volume with. water was used. 
Effect of manganese ions is also seen in Figs. 3(c), 4(c) and 5(c). $\mathrm{Mn}^{++}\left(10^{-6} \mathrm{M}\right)$ stimulated the rate of IAA destruction by both crude and dialyzed extracts prepared from germ-axes of various ages excepting 0 day-old ones. $\mathrm{Mn}^{++}$added also completely reversed the inhibition caused by DCP (Table 1). But $\mathrm{Mn}^{++}$could neither enhance the IAA destroying ability of the extracts from 0 day-old germ-axes nor remove the inhibition induced by exogenous hydroquinone (Table 1). Interaction of manganese and DCP on IAA destroying system was investigated by Hillman and Galston ${ }^{10}$ ) in some details. They pointed to the possibility that $\mathrm{Mn}^{++}$inhibits and promotes IAA destruction in tissue brei containing lower and higher levels of endogenous phenolic cofactors, respectively.

It was described above that dialyzate contained some factor(s) which could inhibit IAA destroying activity. Effect of dialyzate on dialyzed extract is illustrated in Figs. 3(e), 4(e) and 5(e). Figs. 4(e) and 5(e) suggest that the content of the factor(s) is higher in 5 day-old materials than in 2 day-old ones. It is noticeable that dialyzates from both 2 and 5 day-old tissues stimulated the destruction at a lower concentration and inhibited at a higher one. Inhibition by a higher concentration of added dialyzates was also diminished by $\mathrm{Mn}^{++}\left(10^{-5} \mathrm{M}\right)$ (Table 1$)$.

Since any addition, i.e., $\mathrm{Mn}^{++}, \mathrm{H}_{2} \mathrm{O}_{2}$ or DCP, could not evoke IAA destroying ability in 0 day-old extracts at all, the destroying system seems to be not yet functioning in germ-axes at the outset of culture.

Subcellular localization of IAA destruction system.

Subcellular localization of IAA destroying activity was investigated (Fig. 6). Mitochondrial $(M t)$ and supernatant $(S p)$ fractions from 2 day-old materials could

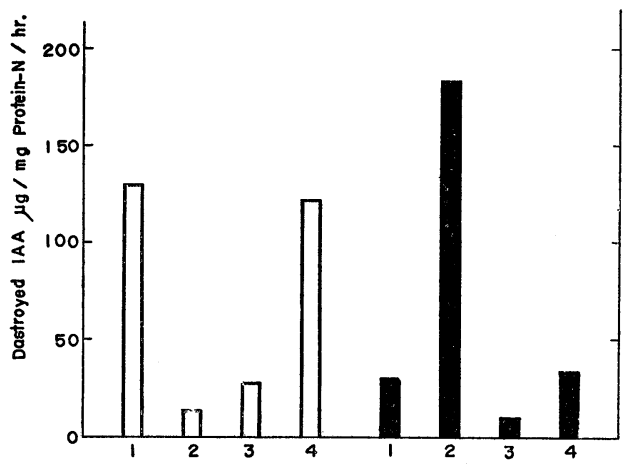

Fig. 6. IAA destruction by subcellular components prepared from 2 (blank bars) and 5 (filled bars) day-old control cultures.

1: crude extract, not fractionated,

2: mitochondrial fraction,

3: supernatant fraction,

4: mitochondrial+supernatant fractions. hardly decompose IAA by themselves, but the recombination of these fractions evoked remarkable decomposition. Moreover, it was clearly demonstrated that the activity of crude extract from 5 dayold tissues was localized almost exclusively in $M t$ fraction, and some inhibiting substance(s) seems to exist in $S p$ fraction. This unknown substance(s), however, cannot be regarded as a simple inhibitor since the addition of small and large amounts of $S p$ from 5 day-old culture to $M t$ from 2 day-old culture stimulated and diminished the IAA destruction, respectively (Table 2). The results are very similar to those obtained in DCP experiments (Figs. 3(a) and $4(\mathrm{a})$ ). As the amount of the active substance in $S p$ increases in some way with culture period, the action of $S p$ may be converted into inhibitory from promotive as was observed. 
Table 2. Subcellular distribution of IAA destroying activity.

\begin{tabular}{l|c}
\hline Fractions added to reaction medium* & $\begin{array}{c}\text { IAA destroyed } \\
(\mu \mathrm{g} . / \mathrm{mg} . \text { protein-N/hr. })\end{array}$ \\
\hline$+M t^{* *}(1 \mathrm{~m} l)$. & 10 \\
$+S p^{* * *}(1 \mathrm{~m} l)$. & 7 \\
$+S p \quad(5 \mathrm{~m} l)$. & 12 \\
$+M t(1 \mathrm{~m} l)+.S p(1 \mathrm{~m} l)$. & 134 \\
$+M t(1 \mathrm{~m} l)+.S p(5 \mathrm{~m} l)$. & 37 \\
\hline
\end{tabular}

* Reaction medium: $0.6 \mathrm{mg}$. IAA in $4 \mathrm{ml}$. of $0.03 \mathrm{M}$ phosphate buffer ( $\mathrm{pH} 6.0$ ); total volume made up to $10 \mathrm{~m} l$. with the buffer. For further explanations, see 'fractionation of crude extract' in the text.

** $\quad M t$ fraction prepared from crude extract of 2 day-old control culture.

*** $S p$ fraction prepared from crude extract of 5 day-old control culture.

\section{Discussion}

In view of the effects of $\mathrm{Mn}^{++}, \mathrm{H}_{2} \mathrm{O}_{2}$, monophenol and polyphenol ${ }^{6-10}$ ), the bulk of IAA destruction by the extract of bean germ-axes appears to involve a peroxidative reaction.

Galston and Dalberg' ${ }^{2}$ ) have found that in pea epicotyls IAA destroying activity is the lowest in the apical zone and increases basipetally along the epicotyl axis, and have suggested that the decrease in IAA level due to the increase of IAA oxidation capacity would be responsible for the cessation of elongation in the aged tissues. Similar result was also reported by Pilet and Galston ${ }^{5}$ ). They observed that in Lens root IAA destruction was the weakest at the meristematic zone and increased toward the maturation zone. In contrast, however, in the present materials, IAA destroying ability, as estimated similarly for crude extract to the above-cited authors, was elevated till the 3rd day of culture, and subsequently declined gradually to complete disappearance without any concomitant fall and rise in water uptake or elongation (Fig. 1). Another widely accepted view is that cell wall extensibility and/or water permeability of protoplasmic membrane are the essential factor for water uptake or elongation of plant tissues ${ }^{11}$ ), and we have previously shown that disappearance of wall extensibility is the major cause of the cessation of water uptake in germinating bean hypocotyl $1^{4}$. At least in the present materials, therefore, IAA destroying activity may have no direct relation with water uptake or tissue elongation.

It is difficult, however, to answer whether IAA decomposing ability as assayed for extracts may reflect precisely the activity of the intact tissues. Separately we estimated the decrease in content of IAA added to a reaction medium in which isolated germ-axes were floated and shaken. Excepting the case where 0 day-old germ-axes were examined, definite loss of IAA from the medium was always found to take place. But it is still questionable if the activity in vivo was exactly measured here, since the decrease of IAA in the medium might simply be due to IAA absorption of the tissues.

The weak IAA destroying activity of crude extracts prepared from aged germaxes was elevated strikingly with dialysis (Fig. 2). This suggests that some dialyzable inhibit or exists in crude extract. The effects of dialyzate and DCP on IAA destruction were found to be remarkably similar to each other; they stimulate the 
destruction at lower concentrations and inhibit at higher ones, and the inhibition is removed by $\mathrm{Mn}^{++}$. Hence a temporary conclusion may be that, in agreement with other authors ${ }^{7,9,10}$ ), some phenolic compound is responsible for the stimulation and the inhibition of IAA destruction in bean germ-axis extract. But an alternative possibility is not entirely excluded that the inhibition and the stimulation are brought forth by different yet unidentified substances, respectively ${ }^{12}$ ). An interesting finding is that in aged germ-axes IAA destroying activity (peroxidase activity ?) and the active substance(s) in question were shown to localize in mitochondrial and $10,000 \times \mathrm{g}$ supernatant fractions, respectively, while in younger cells ( 2 day-old) the activity was manifested only when both fractions were combined. In the present experiments it was also found that IAA destroying ability in dialyzed extract prepared from germ-axes at later culture period was not removed with prolonged dialysis. On the other hand, a purified peroxidase preparation has been shown to be still in combination with some $\left.\operatorname{cofactor}^{8}\right)$. Thus, the exclusive localization of the activity in $M t$ fraction in aged cells may be ascribed to the binding of the active substance (cofactor) from $S p$ fraction with the enzyme protein moiety in $M t$ fraction.

In $I A A$ culture only weak IAA destruction was exhibited for the initial 2 days. This weak activity could not be promoted by dialysis, and likely related to the inhibitory action of auxin added in excess. Separately it has been revealed that the concentration of ether-extractable auxin is the highest in 0 day-old germ-axes as far as the germination stage is concerned. Thus the exogenously supplied IAA may readily rise the auxin level of the tissues over a threshold so that their IAA destroying activity would be depressed. During the initial 2 days of culture this surplus IAA may be destroyed slowly with this remaining weak activity until the IAA concentration falls down below the threshold level, and this would allow more active IAA destruction and normal water uptake to proceed.

\section{Summary}

1. IAA destruction by extracts prepared from bean germ-axes cultured in a medium with or without IAA added was investigated.

2. In control culture (grown without exogenous IAA) IAA destroying activity as measured for crude extract was at its maximum in the 2 day-old materials and decreased henceforth. The declined activity was increased considerably with dialysis of the extract.

3. In IAA culture (grown with exogenous IAA, $1 \mu \mathrm{g} . / \mathrm{ml}$.) IAA destroying activity changed as in control culture but with a definite lag period of 2 days where only weak activity was manifested. This initial depressed activity was not promoted by dialysis.

4. Addition of a small amount of dialyzate from either 2 or 5 day-old tissues to dialyzed extract stimulated IAA destruction, whereas the addition of a large amount inhibited it. This inhibition was reversed with $\mathrm{Mn}^{++}$.

5. Combined with the results obtained especially from the examinations on the effects of $\mathrm{H}_{2} \mathrm{O}_{2}$ and phenols, the involvement of peroxidase reaction in IAA destruction and the presence of an endogenous phenolic substance affecting IAA destroying activity was assumed.

The author wishes to express his sincere gratitudes to Dr. Y. Oota for his kind guidance and advice. 


\section{References}

1) Leopold, A. C., Auxins and Plant Growth, Berkeley (1955). 2) Galston, A. W., and Dalberg, L. Y., Amer. Jour. Bot. 41: 373 (1954). 3) Izawa, M., Bot. Mag. Tokyo 74: 98 (1961). 4) -, Jap. Jour. Bot. 16: 135 (1958). 5) Pilet, P. E., and Galston, A. W., Physiol. Plantarum 8: 888 (1955). 6) Ray, P. M., Ann. Rev. Pl. Physiol. 9: 81 (1958). 7) Kenten, R. H., Biochem. Jour. 59: 110 (1955). 8) Yamazaki, I., Proc. Int. Sym. Enz. Chem. 2: 224 (1958). 9) Goldacre, P. L., Galston, A. W., and Weintraub, R. L., Arch. Biochem. Biophys. 43: 358 (1953). 10) Hillman, W. S., and Galston, A. W., Physiol. Plantarum 9: 230 (1956). 11) Söding, H,. Wuchsstofflehre, Stuttgart (1952). 12) Galston, A. W., in Photoperiodism and Related Phenomena in Plants and Animals, Washington (1959).

\section{摘 要 \\ 井沢三生：ミトリササゲの培養胚に和ける吸水とインドール酢酸分解}

IAA $(1 \mu \mathrm{g} . / \mathrm{m} l$.$) 添加物よび無添加 (対照) それぞれの条件下で組織培養されたミトリササゲ胚の吸水能$ 物よび IAA 分解能は日とともに特色ある変化を示す. 対照培養の吸水能は培㽰期間を通じて不変だが, IAA 分解能はゼ口から出発して 2 日目に極大值に達し, 以後降下して 6 日目にはふたたびゼロになる。 IAA 培養では, 吸水能, 分解能ともに最初の 2 日間顕著な lag を示すが，以後対照培養に見られるのと まったく同様に変化する.

培盖後期の IAA 分解能低下の原因は, 組織の可溶性分画中に, ある種のモノフェノールが蓄積するこ とにあるらしい, 培養初期の胚では, この物質は, その組織内濃度が低いため, むしろ逆に IAA 分解促 進作用を営んでいる可能性が大きい。

IAA 培養初期の低 IAA 分解能は, 外部からの IAA 供給に基づく組織内 IAA 濃度上年にその原因が あると考穴られる。

培養胚の営む IAA 分解はパーオキシダーゼ作用を含むであうう. (名古屋大学理学部生物学教室) 